\title{
Analysis of $\mathrm{HGPRT}^{-} \mathrm{CRM}^{+}$Human Lymphoblast Mutants
}

\author{
J. Epstein, ${ }^{1,6}$ G. S. Ghangas, ${ }^{2,4}$ A. Leyva, ${ }^{3,5}$ G. Milman, ${ }^{2}$ and J. W. Littlefield ${ }^{1}$ \\ 'Department of Pediatrics, Johns Hopkins University School of Medicine and ${ }^{2}$ Department of \\ Biochemistry, Johns Hopkins University School of Hygiene and Public Health, Baltimore, \\ Maryland 21 205; and ${ }^{3}$ Department of Internal Medicine, University of Michigan Medical \\ Center, Ann-Arbor, Michigan 48104
}

Received 13 July 1979

\begin{abstract}
Three 6-thioguanine-resistant mutants of the human diploid lymphoblast line $M G L-8$ were studied. The inactivation by heat of both HGPRT activity and antigenicity of the HGPRT immunologically crossreacting material of the A30 mutant cells were not protected by PRPP, indicating that the HGPRT in A30 cells has an altered PRPP binding site, leading to lack of stabilization and rapid degradation of the enzyme. Two dimensional separations of the immunoprecipitates from extracts of the parental and mutant cell lines showed that the A35 mutant CRM has a more acidic isoelectric $p H$, while the A30 CRM has a more basic isoelectric $p H$ and that the $A 30$ protein has a faster rate of degradation than the wild-type HGPRT. The A30 CRM also has a smaller molecular size than the wild-type enzyme.
\end{abstract}

\section{INTRODUCTION}

We have previously described a series of independent 6-thioguanine (6-TG) resistant mutants derived from a mutagen-treated diploid human lymphoblast cell line. Four of these variants had detectable amounts of immunologically cross-reacting material (CRM) to HGPRT (EC 2.4.2.8, IMP: pyrophosphate phosphoribosyltransferase). Of these, only mutant A30 had significant residual enzyme activity. This was different from the normal

\footnotetext{
${ }^{4}$ Present address: Section of Biochemistry, Cornell University, Division of Biological Sciences, Wing Hall, Ithaca, New York 14853.

${ }^{5}$ Present address: Department of Internal Medicine, Oncology, University Hospital Utrecht, The Netherlands.

${ }^{6}$ Address for reprint requests and present address: Section of Cell Biology, Department of Medical Oncology, Roswell Park Memorial Institute, Buffalo, New York 14263.
} 
enzyme activity in its $K_{m}$ for PRPP and in its $\mathrm{pH}(10-7.4)$ activity ratio. Also, the enzyme activity present in extracts of A30 cells was much more sensitive to inactivation by heat and to degradation by trypsin than the wild-type enzyme (1).

We have studied further three mutants in order to gain better understanding of the nature of the changes resulting in cells with such a phenotype. The results of these studies indicate that the HGPRT in A30 cells has an altered PRPP binding site leading to lack of stabilization and rapid degradation of the enzyme. Also, the A30 enzyme appears to be $3-9$ amino acids shorter than the wild-type protein, perhaps representing a protein chaintermination mutation.

\section{MATERIALS AND METHODS}

Materials. Rabbit and goat antisera against human HGPRT were prepared and characterized as described elsewhere $(2,3)$. Rabbit anti-goat gammaglobulin antiserum was purchased from Antibodies, Inc., Davis, California. $\left[8{ }^{14} \mathrm{C}\right]$ Hypoxanthine $(48.6 \mathrm{mCi} / \mathrm{mmol})$ and $\left[8-{ }^{14} \mathrm{C}\right]$ adenine $(6.5$ $\mathrm{mCi} / \mathrm{mmol})$ were purchased from Amersham, and $\left[{ }^{35} \mathrm{~S}\right]$ methionine $(1.2$ $\mathrm{Ci} / \mathrm{mmol}$ ) from Schwartz-Mann. Tissue culture media were products of GIBCO, and irradiated fetal calf serum was obtained from Microbiological Associates.

Cells. The human lymphoblast cell line MGL8 was established by Dr. H.R. Zielke. Selection and characterization of the 6-TG-resistant mutants A29, A30, and A35 have been described (1). To ensure the phenotypic stability of the mutant lines, duplicate cultures were tested for resistance to 6-thioguanine (6-TG) and sensitivity to HAT medium $(4,5)$.

Enzyme Assays. Logarithmically growing cells were washed twice in

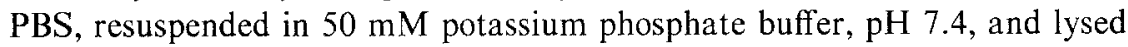
by freeze-thawing twice in a dry ice-ethanol bath. HGPRT activity was measured in a $24,000 \mathrm{~g}$ supernatant. Conditions for the HGPRT assay as well as for the determination of CRM by the immunoprecipitation inhibition test have been described in detail elsewhere (1). Phosphoribosyl pyrophosphate synthetase (PRPP synthetase, ribosephosphate pyrophosphokinase; EC 2.7.6.1) activity was determined in cell extracts prepared as above with $1 \mathrm{mM}$ dithiotreitol (DTT) added to the buffer and dialyzed for $12 \mathrm{~h}$ against $400 \mathrm{vol}$ of the same buffer. PRPP synthetase activity was measured by a modification of the PRPP production assay described by Fox and Kelly (6). The reaction mixture contained cell extract (1-3 $\mu$ g protein), $50 \mathrm{mM}$ potassium phosphate, pH 7.4, $0.5 \mathrm{mM}$ DTT, $0.6 \mathrm{mM}$ ribose 5-phosphate, $6 \mathrm{mM} \mathrm{MgCl}_{2}, 0.1 \mathrm{mM}$ $\left[8{ }^{14} \mathrm{C}\right.$ ]adenine $(6.5 \mathrm{mCi} / \mathrm{mmol})$, and $100 \mu \mathrm{g}$ of 90 -fold purified human erythrocyte adenine phosphoribosyltransferase (PRPP synthetase-free) in a 
final volume of $50 \mu \mathrm{l}$. After $10 \mathrm{~min}$ at $37^{\circ} \mathrm{C}$, the reaction was stopped by adding $10 \mu \mathrm{l}$ of $0.2 \mathrm{M}$ EDTA, and the products analyzed by high-voltage electrophoresis (2).

PRPP Assay. PRPP was determined in nondialyzed cell-free extracts. Logarithmically growing cells were washed twice in PBS, resuspended in 50 $\mathrm{mM}$ potassium phosphate buffer, $\mathrm{pH} 7.4$, containing $0.25 \mathrm{M}$ sucrose and 1 $\mathrm{mM}$ EDTA at $10^{7}$ cells $/ \mathrm{ml}$, and lysed by freeze-thawing. The lysates were immediately immersed in boiling water for $1 \mathrm{~min}$, followed by centrifugation at $100,000 \mathrm{~g}$ for $30 \mathrm{~min}$. Samples of the supernatant were dialyzed against three changes of $100 \mathrm{vol}$ of extraction buffer for $1 \mathrm{~h}$ each to serve as PRPP-free controls. The rest of the extracts were kept at $-70^{\circ} \mathrm{C}$. Reaction

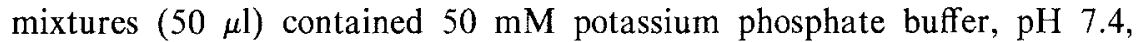
$5 \mathrm{mM} \mathrm{MgCl}, 20 \mu \mathrm{M}\left[8-{ }^{14} \mathrm{C}\right]$ hypoxanthine $(11.2 \mu \mathrm{Ci} / \mathrm{mmol}), 0.5 \mu \mathrm{l}$ of 137-fold purified human erythrocyte HGPRT $(4 \mu \mathrm{g}$ protein, activity $3.7 \times$ $10^{-6} \mathrm{~mol} / \mathrm{h} / \mathrm{mg}$ protein), and $25 \mu \mathrm{l}$ deproteinized cell extract. The reaction mixture was incubated for $60 \mathrm{~min}$ at $37^{\circ} \mathrm{C}$. After incubation, $25 \mu \mathrm{l}$ of each reaction mixture was spotted on a DEAE disk (Whatman DE81). The disks were air dried, washed twice in $1 \mathrm{mM}$ ammonium formate, once in water, and finally in 95\% ethanol. Subsequently, the disks were air dried, and radioactivity counted in a liquid scintillation counter. Under these conditions, $100 \%$ and $98 \%$ of the hypoxanthine and PRPP added, respectively, were converted to IMP as measured by cellulose acetate electrophoresis by the method of Kizaki and Sakurada (7).

Two-Dimensional Polyacrylamide Gel Electrophoresis. Twodimensional polyacrylamide gel electrophoresis was performed as previously described (8) with some modifications. Approximately $10^{8}$ cells were centrifuged at $500 \mathrm{~g}$ for $5 \mathrm{~min}$. The cells were resuspended in $2 \mathrm{ml}$ of Dulbecco's modified Eagle's medium containing 10\% fetal bovine serum but no methionine and placed in $100-\mathrm{mm}$ plastic petri plates. Each plate was immediately supplemented with $0.5 \mathrm{ml}$ of the same medium containing 0.3 $\mathrm{mCi}\left[{ }^{35} \mathrm{~S}\right]$ methionine $(1.2 \mathrm{Ci} / \mathrm{mmol})$. The cells were gently agitated every 15-30 min during a 3-h incubation period. At the end of the incubation, the plates of cells were removed to a cold room, and all further operations were conducted at 0 to $4^{\circ} \mathrm{C}$. The cells were transferred to test tubes, washed twice with ice cold phosphate-buffered saline, and then suspended in $1.5 \mathrm{ml}$ of extraction buffer $(10 \mathrm{mM} \mathrm{MgCl}, 30 \mathrm{mM} \mathrm{KCl}, 0.1 \mathrm{mM}$ DTT, $0.5 \%$ Triton $\mathrm{X}-100$, and $10 \mathrm{mM}$ Tris $\mathrm{HCl}, \mathrm{pH} 7.4$ ) and allowed to stand on ice for $5 \mathrm{~min}$. The suspension was centrifuged at $19,000 \mathrm{~g}$ and the supernatant containing the HGPRT protein was stored in a liquid nitrogen freezer. Before use the thawed cell lysates were centrifuged for $2 \mathrm{~h}$ at $95,000 \mathrm{~g}$ and the high-speed supernatant fractions were subjected to electrophoresis or immunoprecipitation. 
Immunoprecipitation of HGPRT Protein. Immunoprecipitation of HGPRT protein from cell extracts was a modification of the double-antibody procedure previously described $(3,8,9)$. All steps were performed at $0-4^{\circ} \mathrm{C}$. A 500- $\mu$ l high-speed supernatant fraction sample of $\left[{ }^{35} \mathrm{~S}\right]$ methioine-labeled cell extract $\left(5 \times 10^{7} \mathrm{cpm}\right)$ was mixed with $0.6 \mu$ l HGPRT antibody and allowed to stand for 3-4 h. An equivalent of rabbit anti-goat $\gamma$-globulin serum $(6 \mu \mathrm{l})$ was added and the mixture allowed to stand for an additional 5-8 $\mathrm{h}$. The immunoprecipitate was sedimented by centrifugation for $10 \mathrm{~min}$ at $24,000 \mathrm{~g}$. The precipitate was washed twice with extraction buffer containing $0.5 \%$ sodium deoxycholate and either immediately dissolved in lysis buffer containing $9.5 \mathrm{M}$ urea, $2 \%$ Triton X-100, 1.6\% Bio-Rad Biolytes at pH 5-7, $0.4 \%$ Biolytes at $\mathrm{pH} 3-10$, and 5\% 2-mercaptoethanol and applied to an isoelectric focusing gel as previously described (8), or stored in a liquid nitrogen freezer. Usually, one fifth of the immunoprecipitate was applied to an isoelectric focusing gel but greater amounts were used for mutant A29 with low HGPRT cross-reacting material (1).

\section{RESULTS}

Heat Inactivation Studies. Cell extracts were incubated at $80^{\circ} \mathrm{C}$ for different times. Aliquots of the heat-treated extracts of A30 and wild-type L8 cells were assayed for residual HGPRT activity, as well as for residual immunologically recognizable material. The HGPRT activity and the
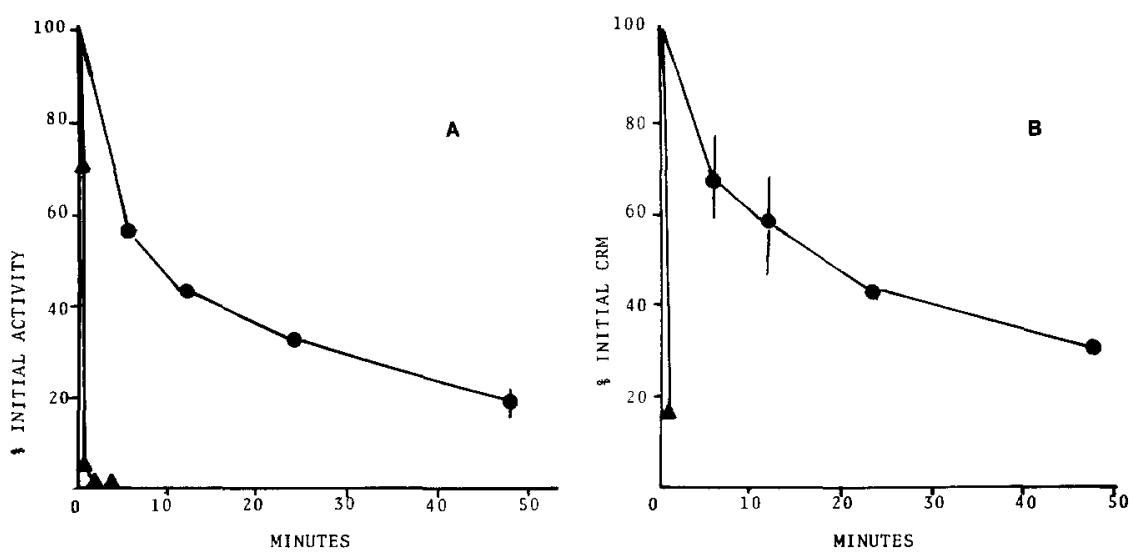

Fig. 1. Thermal inactivation of HGPRT activity and antigenicity. Cell extracts containing 5 $\mathrm{mg} / \mathrm{ml}$ protein were incubated at $80^{\circ} \mathrm{C}$ for different times, chilled in ice water, spun down, and the supernatant diluted and assayed for enzyme activity and CRM as described (1), except that A30 extracts were assayed for $1 \mathrm{~h}$ with $10 \mathrm{mM}$ PRPP. (A) HGPRT activity: The initial activity was 10,308 and $6576 \mathrm{cpm}$ in the extracts of MGL8 and mutant A30, respectively. (B) Antigenicity: Same dilutions were used as in A. MGL8, - A30, A. Bars represent standard errors. 


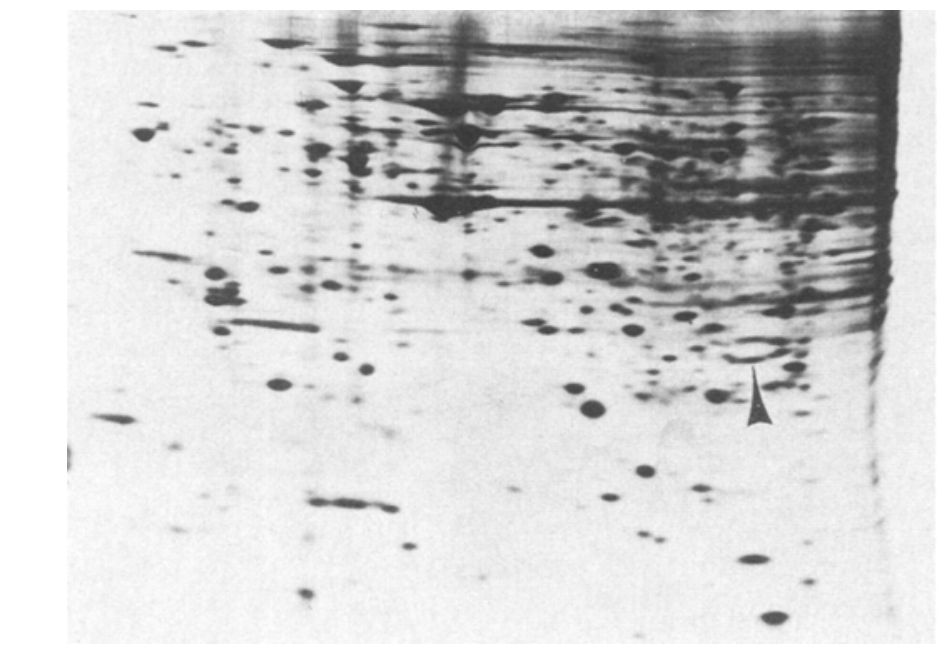

Fig. 2. Autoradiogram of a two-dimensional polyacrylamide gel electrophoresis of extracts of the parental MGL8 cells. Cell proteins were labeled with $\left[{ }^{35} \mathrm{~S}\right]$ methionine and extracts prepared as described in Materials and Methods. A sample of 20-30 $\mu$ l containing 100-150 $\mu \mathrm{l}$ protein and $2-3 \times 10^{6} \mathrm{cpm}$ of $\left[{ }^{35} \mathrm{~S}\right]$ methionine was applied to isoelectric focusing gels with a $\mathrm{pH} 4-7$ linear $\mathrm{pH}$ gradient, and run for $15-16 \mathrm{~h}$ at $400 \mathrm{~V}$ and an additional hour at $800 \mathrm{~V}$. The gels were then exposed to the second-dimension separation of SDS slab gels. The dried gels were exposed to Kodak No-Screen medical $x$-ray film. Detailed description of the method was described in reference 8. Radioautographs are presented with isoelectric focusing $\mathrm{pH} 4$ on the left, and $\mathrm{pH} 7$ on the right. The HGPRT spot is indicated by an arrow.

amounts of CRM present in the extracts were plotted against incubation time, and are presented in Fig. 1A and B. The loss of HGPRT-specific antigenicity in the cell extracts as a result of heat treatment appears to parallel the loss of catalytic activity.

Analysis of CRM. An autoradiogram of a two-dimensional polyacrylamide gel electrophoresis of an extract of the parental MGL8 cells is illustrated in Fig. 2. The spot corresponding to HGPRT is indicated by an arrow. The location of the wild-type HGPRT is consistant with what has been reported for HeLa cells and human erythrocyte $\operatorname{HGPRT}(8,9)$. The HGPRT regions of the autoradiograms of MGL8, A30, and A35 extracts are shown in Fig. 3A, B, and C, respectively. The HGPRT-deficient mutants lack the wild-type HGPRT spot but display new spots, indicated by the arrows in Fig. 3B and $C$. The new HGPRT spot of mutant A35 coincides with another protein spot in the pattern.

Two-dimensional separations of the immunoprecipitates from extracts of the parental cells MGL8 and the mutant clones A30 and A35 are shown in Fig. 4A-E. Figure 4A shows the autoradiogram of the immunoprecipitated HGPRT spot from the MGL8 extract. The autoradiograms of mixtures of the 


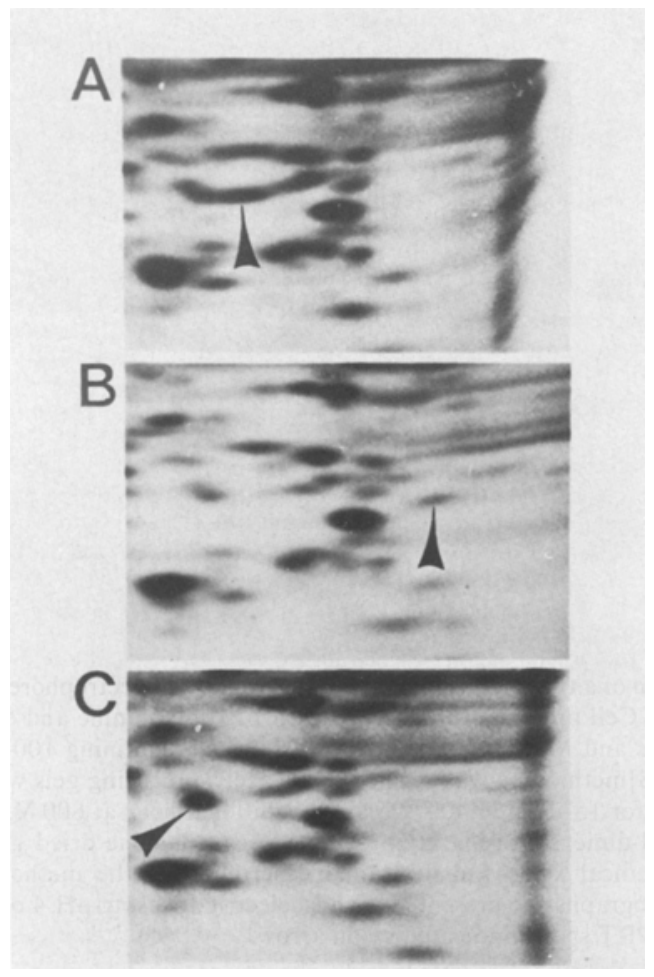

Fig. 3. Autoradiogram of the HGPRT region from two dimensional gels of MGL8 and mutants A30 and A35 extracts: (A) MGL8; (B) A30; (C) A35. The HGPRT spots are indicated by arrows. A new spot in B, not present in the wild-type extracts, is indicated by an arrow head.

immunoprecipitates of A30 and A35 with that of MGL8 are shown in Fig. 4B and $\mathrm{C}$, respectively. The HGPRT spot of mutant A30 is shifted to a more basic isoelectric $\mathrm{pH}$ while that of mutant $\mathrm{A} 35$ is shifted to a more acidic isoelectric $\mathrm{pH}$. The extract of mutant $\mathrm{A} 29$ displayed an immunoprecipitated spot of very low intensity at the same position as the wild-type protein (not shown). Extracts of A34, a CRM-negative mutant (1), showed no detectable cross-reacting HGPRT spot.

The two-dimensional gel in Fig. 4B suggests that the spot corresponding to the A30 protein migrates faster than the wild-type protein in SDS polyacrylamide electrophoresis. To examine this further, immunoprecipitates of wild-type HPRT, A30 HPRT, and a mixture of wild-type and A30 HPRT proteins were subjected to one-dimensional SDS polyacrylamide electrophoresis. The results are given in Fig. 5. The A30 HPRT protein migrates at an apparent molecular weight which is $400-1000$ daltons less 


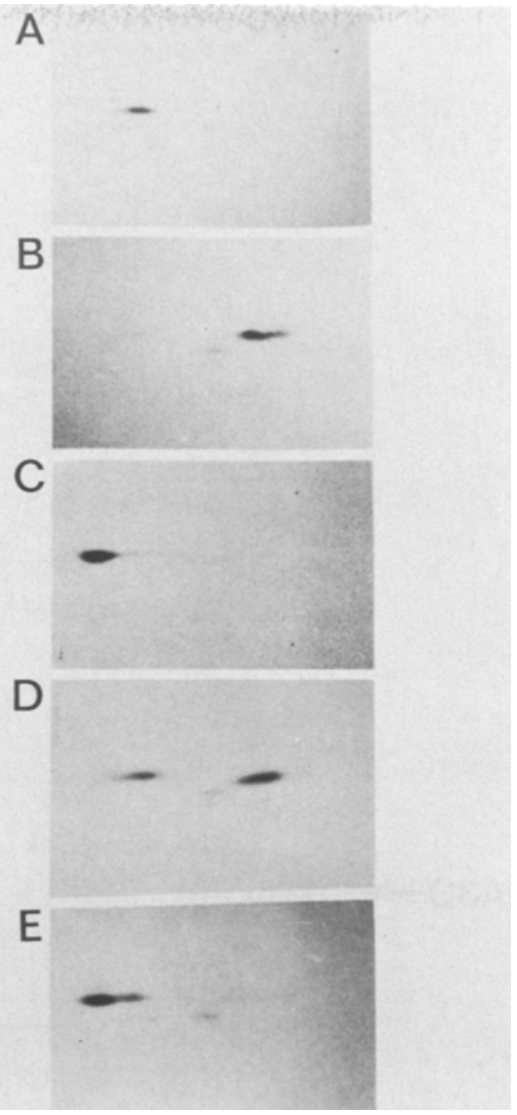

Fig. 4. HGPRT region in two-dimensional polyacrylamide gel autoradiograph of immunoprecipitated (A) wild-type cell extract; (B) A30 cell extract; (C) A35 cell extract; (D) mixture of wild-type and A30 cell extracts; (E) mixture of wild-type and A35 cell extracts. Cell extracts containing $\left[{ }^{35} \mathrm{~S}\right]$ methionine-labeled proteins were reacted with goat anti-human HGPRT serum, followed by rabbit anti-goat $\gamma$-globulin serum as described in Materials and Methods, and the immunoprecipitates were analyzed by two-dimensional electrophoresis.

than the wild-type protein (determined by calibration with molecular-weight markers; data not shown).

Degradation of HGPRT Protein. The gels were also stained for protein with Coomassie blue. The immunoprecipitates and extracts of mutant A30, which give autoradiograms of comparable intensity to those of MGL8 and A35, showed no HGPRT protein in the Coomassie blue stained gels (not shown). Thus, the "specific radioactivity" of the A30 HGPRT is markedly higher. This suggested that the rate of synthesis of the A30 enzyme is similar 


\section{A B C

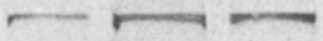

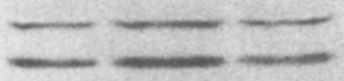

$\mathrm{A3O} \rightarrow \longrightarrow \mathrm{MGL8}$

Fig. 5. Size differences between MGL 8 and A30 HGPRT CRM. Autoradiograph of SDS polyacrylamide gel of immunoprecipitated (A) A30 extract; (B) mixture of A30 and MGL8 extracts; and (C) MGL8 extract.

to that of the MGL8 HGPRT, as indicated by the similar amounts of radiolabeled methionine incorporated during identical incubation periods. However, the rate of degradation of the A30 HGPRT is markedly higher than that of the MGL8 protein, resulting in a relatively high level of radioactivity in a small amount of protein. In contrast, the A35 HGPRT protein appeared to be synthesized and degraded at a similar rate to the MGL8 enzyme.

It has been reported that abnormal proteins in general $(10,11)$, as well as abnormal mammalian HGPRT molecules specifically (12), are degraded preferentially. The rapid degradation of the A30 HGPRT apparent in the polyacrylamide gels is also manifested by the greater sensitivity to heat (Fig. $1)$. 


\begin{tabular}{cccc}
\hline \multicolumn{3}{c}{ Table 1. Effect of PRPP on HGPRT activity } \\
\hline \multirow{2}{*}{ Cells } & $\begin{array}{c}\text { Incubation } \\
\text { time }\end{array}$ & \% of initial activity (SE) \\
\cline { 2 - 4 } & 0 & Control & $1.0 \mathrm{mM}$ PRPP \\
\hline MGL8 & $6 \mathrm{~min}$ & $56(0.1)$ & 100 \\
& $12 \mathrm{~min}$ & $40(0.1)$ & $89.5(0.5)$ \\
A30 & 0 & 100 & $88.0(1.0)$ \\
& $20 \mathrm{sec}$ & $71.0(1.0)$ & $89.5(0.5)$ \\
& $60 \mathrm{sec}$ & $4.8(0.3)$ & $3.85(0.25)^{b}$ \\
\hline${ }^{a}$ Cell extracts to which PRPP wàs added to a final concentration of $1 \mathrm{mM}$ were incubated at \\
$80^{\circ} \mathrm{C}$ and the residual enzyme activity compared to samples heated without PRPP. The \\
procedure and initial activities are identical to that described for Fig. 1. \\
${ }^{b}$ The difference is not significant at the $P \leq 0.05$ level. \\
\hline
\end{tabular}

Stabilization by PRPP. It is known that in the presence of PRPP HGPRT activity shows marked resistance to inactivation by heat (13-15). Since A30 HGPRT has a very high $K_{m}$ for PRPP $\left(6 \times 10^{-2}\right.$ compared with 3 $\times 10^{-5}$ for MGL8) (1), we compared the stabilizing effect of PRPP on enzyme activity and CRM in the cell extracts. Table 1 summarizes the effects of PRPP on the thermal stability of HGPRT activity in the MGL8 and A30 extracts. While the MGL8 enzyme was almost fully protected by $1 \mathrm{mM}$ PRPP against inactivation by $80^{\circ} \mathrm{C}$ for up to $12 \mathrm{~min}$ of incubation, the HGPRT activity in the A30 extracts was but slightly protected and only during the first few seconds of incubation.

The effects of PRPP on the degradation of CRM are similar to its effect on enzyme activity (Table 2). While the MGL8 enzyme protein was well protected, there was no protection of the A30 CRM. The proteins from the two mutants with no detectable catalytic activity, A35 and A29, were also not protected by PRPP. Incidentally, Table 2 shows that while the A35 CRM, like that from the A29 and A 30 mutants, is not protected by PRPP, its rate of inactivation is not significantly higher than that of the MGL8 enzyme. This is consistent with the two-dimensional gel results discussed above. Comparing

\begin{tabular}{|c|c|c|c|}
\hline \multirow[b]{2}{*}{ Cells } & \multirow{2}{*}{$\begin{array}{l}\text { Incubation } \\
\text { time }\end{array}$} & \multicolumn{2}{|c|}{$\%$ of initial CRM (SE) } \\
\hline & & Control & $1.0 \mathrm{mM}$ PRPP \\
\hline MGL8 & $12 \mathrm{~min}$ & $49.0(1.0)$ & $83.0(0.1)$ \\
\hline A 35 & $12 \mathrm{~min}$ & $42.5(4.5)^{b}$ & $44.0(0.1)^{c}$ \\
\hline A30 & $1 \mathrm{~min}$ & $16.5(1.5)$ & $19.0(0.1)^{c}$ \\
\hline A29 & $1 \mathrm{~min}$ & $<5$ & $<5$ \\
\hline \multicolumn{4}{|c|}{$\begin{array}{l}{ }^{a} \text { Cell extracts were incubated at } 80^{\circ} \mathrm{C} \text { as in Table } 1 \text {. CRM was determined as described (1) } \\
{ }^{b} \text { Difference between A35 and MGL8 is not significant. } \\
{ }^{c} \text { Not significant at the } P \leq 0.05 \text { level. }\end{array}$} \\
\hline
\end{tabular}




\begin{tabular}{lcccc}
\hline \multicolumn{5}{c}{ Table 3. PRPP synthetase activity and PRPP levels } \\
\cline { 2 - 5 } & MGL8 & A29 & A30 & A35 \\
\cline { 2 - 5 } & $170.5(16.5)$ & $244(26)$ & $259(26)$ & $166.5(6.5)$ \\
\hline $\begin{array}{c}\text { PRPP syn. activity (SE) } \\
(\mathrm{nmol} / \mathrm{h} / \mathrm{mg} \text { protein) } \\
\begin{array}{c}\text { PRPP levels (SE) } \\
\left(\mathrm{nmol} / 10^{7} \text { cells) }\right.\end{array}\end{array}$ & $0.69(0.03)$ & - & $1.11(0.2)$ & - \\
\hline
\end{tabular}

the thermal inactivation of the A30 enzyme activity with the inactivation of its CRM (Fig. 1 and Tables 1 and 2) suggests that the enzyme activity of this mutant enzyme is more heat labile than the specific antigenic structure of the HGPRT molecule.

PRPP Synthetase and PRPP Levels. The lack of protection by $1 \mathrm{mM}$ PRPP of mutant HGPRT activity and CRM against inactivation by heat suggested that unless these cells have a markedly increased intracellular PRPP synthetase activity, and PRPP concentration, the lack of stabilization by PRPP could be the reason for the rapid degradation in vivo of the mutant HGPRT. Therefore, we measured PRPP synthetase activity and PRPP levels in extracts of the parental MGL8 cells and mutants A29, A30, and A35. The enzyme activity found in A29 and A30 extracts was higher than the MGL8 activity but only by 43 and $52 \%$, respectively, and the cellular PRPP level of A30 cells was only $61 \%$ higher than that in the MGL8 cells (Table 3 ).

\section{DISCUSSION}

We have studied the HGPRT protein of three 6-TG-resistant mutants of the human lymphoblast cell line MGL8. Two of the CRM-positive mutants, namely A30 and A35, had structurally altered HGPRT protein, as is evident from the altered isoelectric pH. The molecular weight data in Fig. 5 suggest that A30 HGPRT protein is 3-9 amino acids shorter than the wild-type protein. The most likely explanation for an active protein with small deletion would be a chain-termination mutation near the carboxylterminus of the protein, i.e., the conversion of a code work for an amino acid near the end of the protein to one of those (UAA, UAG, or UGA) which code for protein chain termination during protein synthesis. The alteration in the isoelectric $\mathrm{pH}$ of A30 HGPRT protein would result if one of the amino acids deleted were glutamic or aspartic acid. The radioisotopic amino acid incorporation and peptide mapping techniques previously described (16) may permit confirmation of these predictions.

While the immunoprecipitates of the enzyme of these two mutants gave autoradiogram spots of comparable intensity to that of the wild type, the Coomassie blue-stained gels of the A30 precipitate showed a very faint 
protein spot containing all the radioactivity. This suggested that the A30 HGPRT is being synthesized at the same rate as the normal enzyme but is present in A30 cells in much lesser amounts. The low amount of CRM present in the A30 extracts is consistent with this interpretation (1). Cellular levels of protein are determined by the balance between the rates at which they are synthesized and degraded. In fact, selective degradation of abnormal proteins has been suggested as a protective mechanism against the intracellular accumulation of physiologically defective molecules $(17,18)$. Cepacchi et al. (12) have studied selective degradation of mutant HGPRT molecules in a series of missense mutants of mouse L-cells.

Our data regarding the thermal stability of CRM suggests that two of the mutants, A29 and A30, contained HGPRT protein which was more labile to heat than the wild-type enzyme, while the A35 CRM showed no such difference. Comparison between the thermal inactivation of enzyme activity and of CRM in A30 extracts indicates that the former is more sensitive to heat than the latter.

PRPP protected the normal enzyme of the parental MGL8 cells against the inactivation by heat of both enzyme activity and antigenicity. A30 enzyme is only very slightly protected by the concentration of PRPP used $(1 \mathrm{mM})$. While A30 cells contain $61 \%$ more PRPP than wild-type cells, this increase would not protect A30 HGPRT in view of its low recognition of PRPP as evidenced by a very high $K_{m}$ (1). It seems likely that lack of protection by PRPP, probably due to a change in the PRPP binding site, leads to rapid degradation and causes the low amounts of HGPRT CRM present in the A30 mutant cells. The low ratio of enzyme activity to CRM in these cells (1) perhaps reflects the sequence of the degradation process of the mutant HGPRT in which the loss of enzyme activity precedes the loss of antigenicity.

\section{ACKNOWLEDGMENTS}

The studies reported in this paper were supported in part by U.S.P.H.S. grants CA 16754 and CA 21650.

\section{LITERATURE CITED}

1. Epstein, J., Leyva, A., Kelly, W. M., and Littlefield, J. W. (1977). Somat. Cell Genet. 3:135-148.

2. Arnold, W. J., Mead, J. C., and Kelly, W. N. (1972). J. Clin. Invest. 51:1805-1812.

3. Ghangas, G. S., and Millman, G. (1975). Proc. Natl. Acad. Sci. U.S.A. 72:4147-4150.

4. Szybalski, W., Szybalska, E. H., and Ragni, G. (1962). Natl. Cancer Inst. Monogr. 7:75-89.

5. Littlefield, J. W. (1966). Exp. Cell Res. 41:190-196.

6. Fox, I. H., and Kelly, W. N. (1971). J. Biol. Chem. 246:5739-5748. 
7. Kizaki, H., and Sakurada, T. (1977). J. Lab. Clin. Med. 89:1135-1144.

8. Millman, G., Lee, E., Ghangas, G. S., McLaughlin, J., and George, M., Jr. (1976). Proc. Natl. Acad. Sci. U.S.A. 73:4589-4593.

9. Ghangas, G. A., and Millman, G. (1977). Science 196:1119-1120.

10. Goldberg, A. L. (1972). Proc. Natl. Acad. Sci. U.S.A. 69:422-426.

11. Lin, S., and Zabin, J. (1973). J. Biol. Chem. 247:2205-2211.

12. Capecchi, M. R., Capecchi, N. E., Hughes, S. H., and Wahl, G. H. (1974). Proc. Natl. Acad. Sci. U.S.A. 71:4732-4736.

13. Arnold, W. J., and Kelly, W. N. (1971). J. Biol. Chem. 246:7398-7404.

14. Olsen, A. S., and Millman, G. (1974). J. Biol. Chem. 249:4030-4037.

15. Greene, M. L., Boyle, J. A., and Seegmiller, J. E. (1970). Science 167:887-889.

16. Millman, G., Krauss, S. W., and Olsen, A. S. (1977). Proc. Natl. Acad. Sci. U.S.A. 74:926-930.

17. Pine, M. J. (1972). Annu. Rev. Microbiol. 26:103-126.

18. Goldbert, A. L., Howell, E. M., Li, E. B., Martel, S. B., and Proutz, W. F. (1974). Fed. Proc. 33:1112-1120. 